\title{
The Mungbean Yellow Mosaic Begomovirus Transcriptional Activator Protein Transactivates the Viral Promoter-Driven Transgene and Causes Toxicity in Transgenic Tobacco Plants
}

\author{
Rajendran Rajeswaran, ${ }^{1}$ Sukumaran Sunitha, ${ }^{1}$ Padubidri V. Shivaprasad, ${ }^{1,2}$ Mikhail M. Pooggin, ${ }^{2}$ \\ Thomas Hohn, ${ }^{2}$ and Karuppannan Veluthambi ${ }^{1}$ \\ ${ }^{1}$ Department of Plant Biotechnology, School of Biotechnology, Madurai Kamaraj University, Madurai-625021, India; ${ }^{2}$ Institute \\ of Botany, University of Basel, Schoenbeinstrasse 6, CH-4056 Basel, Switzerland
}

Submitted 24 April 2007. Accepted 21 August 2007.

\begin{abstract}
The Begomovirus transcriptional activator protein (TrAP/ $\mathrm{AC2} / \mathrm{C2})$ is a multifunctional protein which activates the viral late gene promoters, suppresses gene silencing, and determines pathogenicity. To study TrAP-mediated transactivation of a stably integrated gene, we generated transgenic tobacco plants with a Mungbean yellow mosaic virus (MYMV) AV1 late gene promoter-driven reporter gene and supertransformed them with the MYMV TrAP gene driven by a strong $35 \mathrm{~S}$ promoter. We obtained a single supertransformed plant with an intact $35 \mathrm{~S}-\mathrm{Tr} A P$ gene that activated the reporter gene 2.5 -fold. However, 10 of the 11 supertransformed plants did not have the $\operatorname{Tr} A P$ region of the T-DNA, suggesting the likely toxicity of TrAP in plants. Upon transformation of wild-type tobacco plants with the $\operatorname{Tr} A P$ gene, six of the seven transgenic plants obtained had truncated T-DNAs which lacked TrAP. One plant, which had the intact $\operatorname{TrAP}$ gene, did not express TrAP. The apparent toxic effect of the $\operatorname{Tr} A P$ transgene was abolished by mutations in its nuclear-localization signal or zinc-finger domain and by deletion of its activation domain. Therefore, all three domains of $\operatorname{TrAP}$, which are required for transactivation and suppression of gene silencing, also are needed for its toxic effect.
\end{abstract}

Additional keywords: geminiviruses, negative selection.

Geminiviruses encapsidate small, circular, single-stranded DNA genomes of 2.5 to $3 \mathrm{~kb}$. Based on their genome organization, species of insect that transmits the virus, and host range, geminiviruses are classified into four genera: Mastrevirus, Curtovirus, Topocuvirus, and Begomovirus (Fauquet and Stanley 2005). In begomoviruses, expression of the late genes coding for coat protein (AV1) and nuclear shuttle protein (BV1), is dependent on the viral transcriptional activator protein (TrAP/AC2/C2/AL2) encoded by the early gene $\operatorname{Tr} A P$ (Haley et al. 1992; Shivaprasad et al. 2005; Sunter and Bisaro 1991, 1992). TrAP also is involved in the suppression of gene silencing (Bisaro 2006; Trinks et al. 2005; Vanitharani et al. 2005; Voinnet et al. 1999; Wang et al. 2005) and acts as a pathoge-

R. Rajeswaran and S. Sunitha contributed equally to this article.

Corresponding author: K. Veluthambi; Telephone: +91 452 2458683; Fax: +91 452 2459105; E-mail: kveluthambi@ @ediffmail.com nicity determinant (Hong et al. 1996, 1997). TrAP has three functional domains: a basic domain with the bipartite nuclear localization signal (NLS) at the N-terminus, a nonclassical zinc-finger domain in the middle, and an acidic activation domain at the C-terminus (Hartitz et al. 1999; Trinks et al. 2005). Because of high conservation of the functional domains, TrAP mutation in one begomovirus can be functionally complemented by $\operatorname{TrAP}$ of a second begomovirus (Saunders and Stanley 1995; Sunter et al. 1994). TrAP of monopartite begomoviruses share a high level of sequence similarity with that of bipartite begomoviruses (Noris et al. 1996; van Wezel et al. 2001) and are comparable in domain organization (Dong et al. 2003; van Wezel et al. 2001, 2002, 2003), transactivation, suppression of gene silencing, and pathogenicity determination (Dong et al. 2003; Dry et al. 2000; Krake et al. 1998; Rigden et al. 1994; van Wezel et al. 2001, 2002, 2003). Even though a conserved cis-element in the late begomoviral promoters (ArguelloAstorga et al. 1994) was shown to be needed for the activation by TrAP in Pepper huasteco virus (PHV) (Ruiz-Medrano et al. 1999), no consensus TrAP-responsive sequence has been identified to date (Shivaprasad et al. 2005; Sunter and Bisaro 2003). Sunter and Bisaro (2003) showed that the regulation of the AV1 promoter is more complex and involves a bipartite sequence. Because TrAP binds to double-stranded DNA in a sequence-nonspecific manner, the interaction between TrAP and late begomoviral promoters also may be indirect, as in the case of E1a protein of adenovirus (Hartitz et al. 1999; Noris et al. 1996).

Mungbean yellow mosaic virus (MYMV) is a bipartite begomovirus (Karthikeyan et al. 2004) and its TrAP has all three conserved domains (Trinks et al. 2005). TrAP-mediated transactivation of the MYMV AV1 and BV1 promoters as well as the $\mathrm{BC} 1$ promoter was demonstrated by transient expression studies in Nicotiana plumbaginifolia protoplasts (Shivaprasad et al. 2005; Trinks et al. 2005). In addition, RNA profiling in Arabidopsis protoplasts has revealed that transient expression of MYMV TrAP and its homolog from African cassava mosaic virus (ACMV) activates transcription of the same set of host genes (Trinks et al. 2005). Earlier, using tobacco and cassava protoplasts, Frey and associates (2001) showed transactivation of the ACMV promoters by TrAP. Furthermore, transactivation of Tomato golden mosaic virus (TGMV) late gene promoters by TrAP was demonstrated in protoplasts of $N$. tabacum and N. benthamiana (Sunter and Bisaro 1991, 1992, 2003). Integrated copies of begomovirus late gene promoters in transgenic 
plants were shown to be transactivated by transient expression of TrAP, using agroinoculation of leaf discs of transgenic plants (Haley et al. 1992) and agroinoculation of the transgenic plants with the infectious virus clones (Hong et al. 1996; Sunter and Bisaro 1997) or by transient expression of TrAP from a PVX vector (Hong et al. 1997). Sunter and Bisaro (1997) showed that TrAP is required for the expression of the AV1 promoter in both mesophyll and phloem tissues. In the mesophyll cells, TrAP is involved in the activation of the AV1 promoter whereas, in the phloem tissue, TrAP causes its derepression. Transactivation of an integrated copy of the PHV AV1 promoter in transgenic plants also was demonstrated by particle bombardment with a TrAP-expressing plasmid (RuizMedrano et al. 1999). Transactivation of begomovirus promoter has not been demonstrated to date with an integrated copy of a TrAP gene. Interestingly, TrAP has been proposed to be toxic (Hao et al. 2003; Hartitz et al. 1999; Hong et al. 1997; Sunter et al. 2001). However, no clear experimental evidence has been reported thus far for this toxicity.

Legume-infecting Old World begomoviruses are evolutionarily distinct from the remaining viruses in this genus (Qazi et al. 2007). Thus, it is of interest to study the function of TrAP in this group of begomoviruses. In this article, we report for the first time that an integrated copy of MYMV TrAP transactivates the MYMV AV1 promoter in a transgenic N. tabacum plant. We also report that almost all of the transgenic tobacco plants obtained by transformation with the $35 \mathrm{~S}$ promoterdriven TrAP gene had truncated T-DNAs lacking either all or part of $\operatorname{Tr} A P$. These results suggest that constitutive expression of TrAP is toxic to plants. Mutations in the TrAP NLS and zinc-finger domains and deletion of the activation domain, which are required for transactivation and suppression of silencing, abolished the toxic effect of TrAP.

\section{RESULTS}

\section{Transactivation of MYMV AV1 promoter}

by $\operatorname{TrAP}$ in protoplasts and transgenic plants.

The AV1 promoter, defined as the 420-bp fragment upstream of the AV1 open reading frame, was fused to a bean catalase intron-containing $\beta$-glucuronidase $(G U S)$ gene and introduced into the binary plasmid pPZP211 with the $35 \mathrm{~S}$ promoter-driven neomycin phosphotransferase II gene (NPTII) as selection marker (pPZP-AV1) (Fig. 1A). First, transactivation of the AV1 promoter by TrAP was evaluated by transient expression in N. plumbaginifolia protoplasts. For this purpose, the protoplasts were transfected with either pPZP-AV1 alone or together with p35S-TrAP, a plasmid expressing TrAP under 35S promoter. A plasmid constitutively expressing the CAT gene (p35SCAT) was cotransfected to serve as an internal control and to
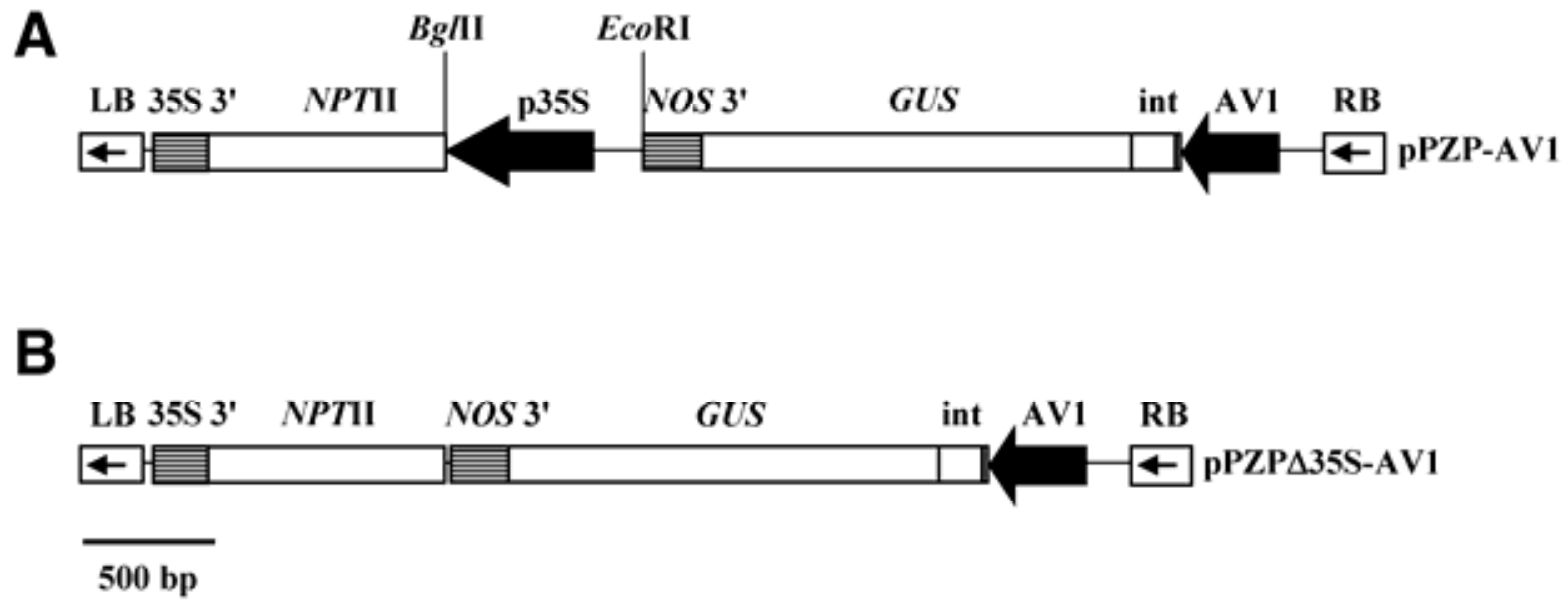

Fig. 1. T-DNA regions of the binary vectors used for transfection of Nicotiana plumbaginifolia protoplasts. A, The plasmid pPZP-AV1 harbors AV1 promoter $(420 \mathrm{bp})$ fused to int- $\beta$-glucuronidase $(G U S)$ gene in the binary vector pPZP211. It has the $35 \mathrm{~S}$ promoter-driven $N P T I I$ gene as a plant transformation marker. B, The plasmid pPZP $35 \mathrm{~S}-\mathrm{AV} 1$ harbors AV1-GUS fusion in pPZP211 with a promoter-less NPTII gene. RB: T-DNA border-right, int: bean catalase intron, NOS 3': nopaline synthase polyadenylation signal, p35S: Cauliflower mosaic virus (CaMV) 35S promoter, NPTII: neomycin phosphotransferase II gene, 35S 3': CaMV 35S polyadenylation signal, LB: T-DNA border-left.

Fig. 2. Transactivation of AV1 promoter by transcriptional activator protein (TrAP) in transgenic tobacco. A, Plasmid pGA-AV1 harbors AV1 promoter (420 bp) fused to int- $\beta$-glucuronidase $(G U S)$ in pGA472, a binary vector with $\mathrm{p} N O S$-driven NPTII as plant transformation marker. B, Plasmid pCAM-TrAP harbors $T r A P$ gene of Mungbean yellow mosaic virus (MYMV)-Vig under the control of Cauliflower mosaic virus (CaMV) $35 \mathrm{~S}$ promoter and hygromycin phosphotransferase gene $(H P H)$ as plant transformation marker. RB: T-DNA border-right, pNOS: nopaline synthase gene promoter, NPTII: neomycin phosphotransferase II gene, NOS 3': nopaline synthase polyadenylation signal, int: bean catalase intron, p35S: CaMV 35S promoter, TrAP: MYMV-Vig TrAP gene, 35S 3': CaMV 35S polyadenylation signal, LB: T-DNA border-left. Probes used are marked in dotted lines. The junction fragment sizes and internal T-DNA fragment (TrAP) size are marked below the arrows. C, Southern blot analysis of tobacco plants transformed with pGA-AV1. Total DNA from 11 transformed plants that regenerated and rooted under kanamycin selection was digested with HindIII and probed with NPTII coding sequence. Undigested DNA from one of the transgenic plants (U) and DNA from nontransgenic control tobacco plant digested with HindIII (C) were used as controls. $\lambda /$ HindIII was used as marker. Junction fragments of $>2.4$ kb from transgenic plants are expected to hybridize. D and E, Southern blot analysis of AV1-GUS plants supertransformed with pCAM-TrAP. Total DNA from six plants of line T1 (1.1 to 1.6), three plants of line T3 (3.1 to 3.3), three plants of line T4 (4.1 to 4.3), and three plants of line T10 (10.1 to 10.3) supertransformed with pCAM-TrAP was digested with EcoRI and probed with $H P H$ coding sequence. Junction fragments of $>2.3 \mathrm{~kb}$ from transgenic plants are expected to hybridize. F, Southern blot analysis of T1.1 plant with TrAP probe. DNA from T1.1 was digested with EcoRI and probed with TrAP coding sequence. The binary plasmid pCAM-TrAP digested with EcoRI (B) was used as a positive control. A 1-kb ladder (Invitrogen, Carlsbad, CA, U.S.A.) was used as marker (M). An internal EcoRI T-DNA fragment of $0.4 \mathrm{~kb}$ is expected to hybridize from transgenic plants and the binary plasmid control (B). G, Northern blot analysis of T1.1 plant. Total RNA samples from the untransformed control (C), parent (T1), and a plant supertransformed with $\operatorname{TrAP}$ (T1.1) were electrophoresed in a 1.2\% agarose gel with $1 \%$ formaldehyde and probed with TrAP coding sequence. The $18 \mathrm{~S}$ rRNA portion of the ethidium-bromide-stained gel is placed at the bottom to show equal loading of RNA in all the lanes. Sizes of an RNA standard are marked on the left. 


\section{A}

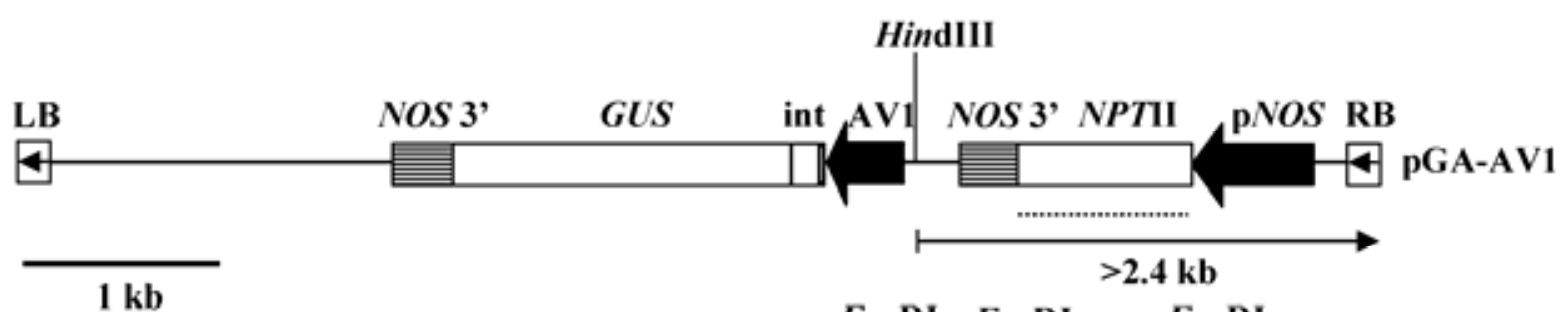

B

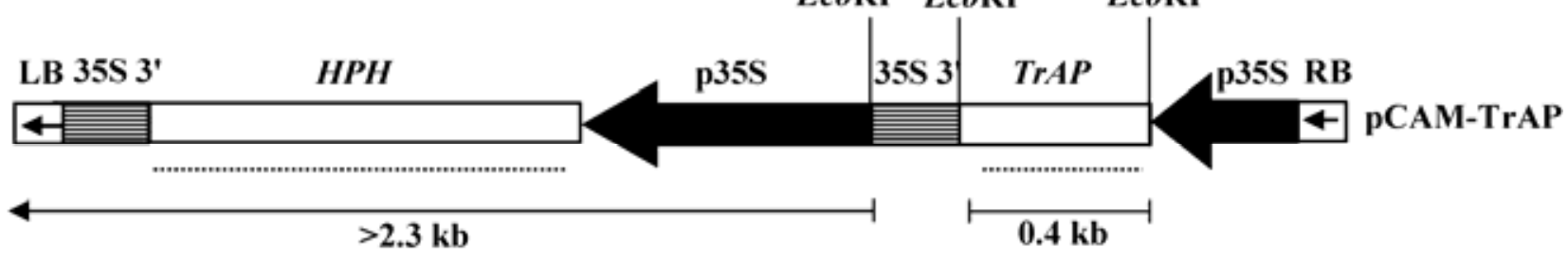

500 bp
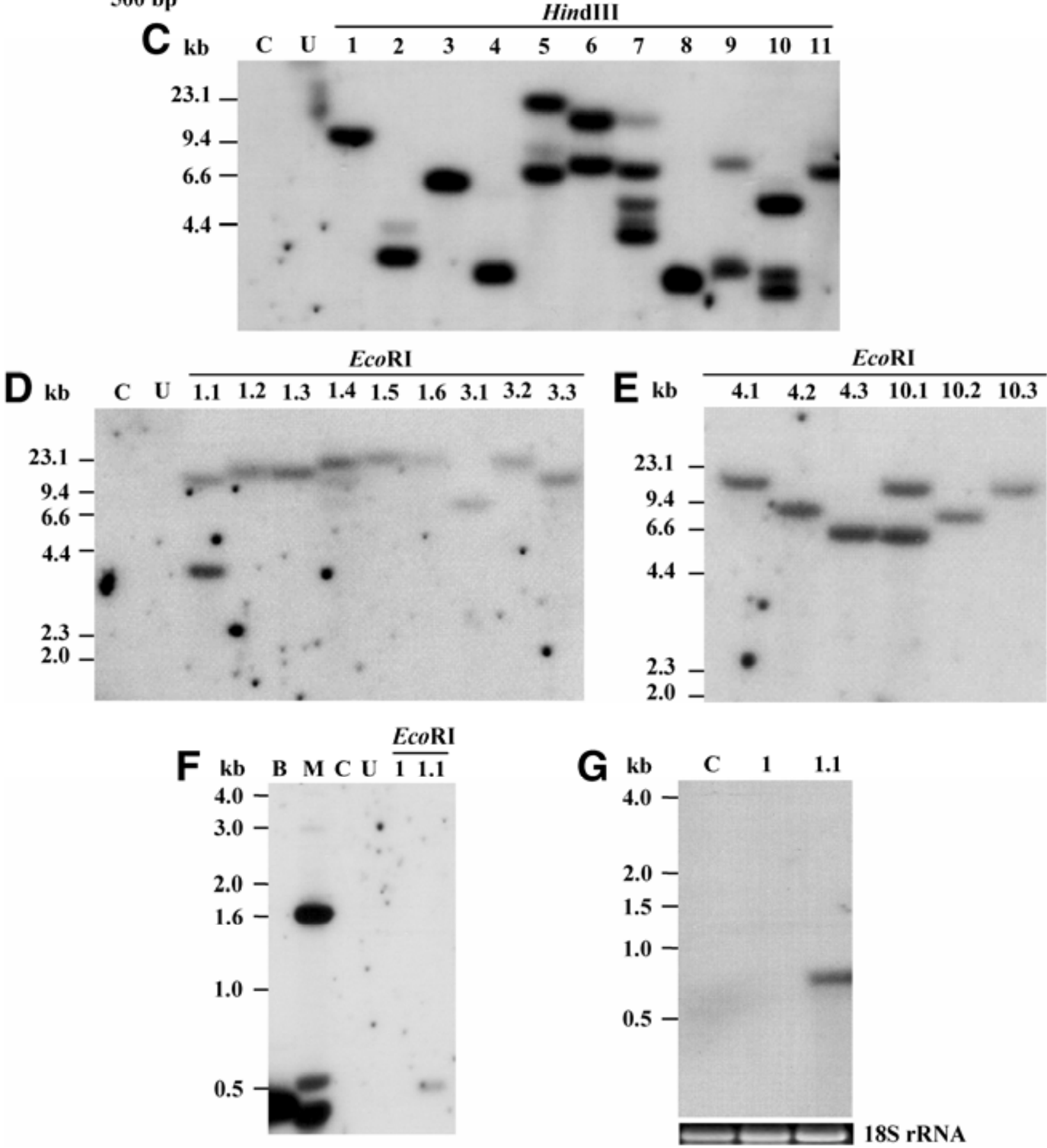
normalize GUS expression levels. The AV1-GUS fusion in pPZP-AV1 showed a low basal GUS activity and was activated fourfold by TrAP (Table 1). A basal level of GUS expression also was observed in tobacco plants stably transformed with pPZP-AV1 (data not shown). It is likely that the enhancer element of the $35 \mathrm{~S}$ promoter of the NPTII gene in pPZP-AV1 contributed to the moderate basal activity of AV1-GUS, a problem previously reported by Yoo and associates (2005).

To check this possibility, the $35 \mathrm{~S}$ promoter of the NPTII gene in pPZP-AV1 was deleted (Fig. 1B). As expected, the basal (TrAP-independent) AV1-GUS activity was reduced (11fold) in $N$. plumbaginifolia protoplasts upon deletion of the $35 \mathrm{~S}$ promoter of NPTII gene. Nevertheless, the AV1-GUS gene in pPZP $\triangle 35 \mathrm{~S}-\mathrm{AV} 1$ was activated 4.3 -fold in the presence of TrAP (Table 1). To obtain tighter control of AV1-GUS expression, the AV1-GUS fusion was subcloned in the pGA472 binary vector with the NPTII gene under the control of NOS promoter (pGA-AV1) (Fig. 2A). Tobacco plants transformed with pGAAV1 were selected on kanamycin and integration of the T-DNA was confirmed by Southern blotting (Fig. 2C). Of the 11 plants transformed with pGA-AV1, 10 showed very weak or no TrAPindependent GUS expression and 1 plant (T10) had moderate GUS activity (data not shown). We found that plants T1, T3, T4, and T8 had single T-DNA insertions, whereas other plants had two or more insertions.

To study transactivation of the integrated AV1-GUS, T1, T3, T4, and T10 plants were supertransformed with Agrobacterium spp. harboring the binary plasmid pCAM-TrAP (Fig. 2B), which contains a hygromycin phosphotransferase gene $(H P H)$ as plant transformation marker and 35S-TrAP. Six supertransformed plants were obtained for $\mathrm{T} 1$ and three each for the plants T3, T4, and T10. All 15 supertransformed plants had one to two copies of the $H P H$ gene (Fig. 2D and E). Unexpectedly, polymerase chain reaction (PCR) analysis showed that only one of them (T1.1) had the TrAP gene (data not shown). To check the presence of intact $\operatorname{Tr} A P$ in the T1.1 plant, its DNA was digested with EcoRI and probed with the TrAP-coding sequence. Because there are two EcoRI sites flanking the TrAP gene in pCAM-TrAP (Fig. 2B), the presence of intact $\operatorname{TrAP}$ coding sequence will result in the hybridization of an internal T-DNA fragment of $0.4 \mathrm{~kb}$. Any truncation in $\operatorname{Tr} A P$ prior to T-DNA integration will result in the formation of a direct junction between TrAP and plant DNA. Consequently, $E c o$ RI digestion will release a $\operatorname{Tr} A P$-hybridizing junction frag-

Table 1. Transactivation of AV1- $\beta$-glucuronidase (GUS) fusion by 35Stranscriptional activator protein (TrAP) gene in Nicotiana plumbaginifolia protoplasts $^{\mathrm{a}}$

\begin{tabular}{|c|c|c|c|}
\hline \multicolumn{2}{|c|}{ AV1-GUS } & \multicolumn{2}{|c|}{$\triangle 35 S$ AV1-GUS } \\
\hline$-\operatorname{Tr} A P$ & $+\operatorname{TrAP}$ & $-\operatorname{Tr} A P$ & $+\operatorname{Tr} A P$ \\
\hline $76 \pm 31$ & $302 \pm 132$ & $7 \pm 3$ & $30 \pm 7$ \\
\hline
\end{tabular}

${ }^{a}$ GUS activity of AV1 promoter fusion in pPZP-AV1 (AV1-GUS) and pPZP $\triangle 35 \mathrm{~S}-\mathrm{AV} 1(\triangle 35 \mathrm{~S}-\mathrm{AV} 1-G U S)$ is shown in the absence and presence of the 35S-TrAP. GUS activity is shown as mean percentage value normalized using CAT levels. GUS values are represented as mean \pm standard deviation of three replicate assays.

Table 2. Summary of Southern blot analysis of tobacco plants transformed with pCAM-transcriptional activator protein- $\beta$-glucuronidase

\begin{tabular}{|c|c|c|c|c|c|c|c|c|}
\hline \multirow[b]{2}{*}{ Gene } & \multicolumn{7}{|c|}{ Plant number } & \multirow{2}{*}{$\begin{array}{c}\text { Total } \\
\text { plants }(\%)\end{array}$} \\
\hline & W1 & W2 & W3 & W4 & W5 & W7 & W10 & \\
\hline$B A R$ & + & + & + & + & + & + & + & 100 \\
\hline GUS & + & + & - & - & - & - & - & 28.5 \\
\hline $\operatorname{Tr} A P$ & - & + & - & - & - & - & - & 14 \\
\hline
\end{tabular}

ment larger or smaller than $0.4 \mathrm{~kb}$. Hybridization of $\operatorname{Tr} A P$ to a 0.4-kb fragment in the plant T1.1 (Fig. 2F) confirmed that an intact $\operatorname{Tr} A P$ is integrated. In a Northern hybridization analysis with $\operatorname{Tr} A P$, the plant T1.1 was found to accumulate the expected approximately $0.7-\mathrm{kb} \operatorname{Tr} A P$ transcript (Fig. 2G). Furthermore, sequencing of a fragment obtained by reverse-transcription PCR confirmed the presence of the wild-type TrAP sequence (data not shown). Fluorometric GUS assay revealed a 2.5-fold increase in GUS-specific activity (data not shown), confirming its transactivation function. None of the other supertransformed plants showed an increase in GUS staining (data not shown).

Expression of TrAP causes toxic effect in transgenic plants.

To further evaluate why a large number of $\operatorname{Tr} A P$-transformed plants show deletion of TrAP in the integrated T-DNA, N. tabacum plants were transformed with a binary vector containing the MYMV 35S-TrAP gene flanked by a 35S-BAR gene and 35S-GUS gene (pCAM-TrAP-GUS) (Fig. 3A). In this configuration of the T-DNA, phosphinothricin (PPT)-resistant and GUS-positive plants are expected to have the intact T-DNA, including the MYMV TrAP. Southern blot analysis (Fig. 3B) of 10 PPT-resistant plants (W1 to W10) with the $B A R$ probe showed that all of them had one or more copies of the $B A R$ gene (Table 2). Junction fragment analysis revealed that W5/W6/W8 and W9/W10 were independent plants that regenerated from the same transformation event. Southern blot analysis with the $\operatorname{TrAP}$ probe (Fig. 3C) showed that only one of the transformed plants (W2) had the intact TrAP gene and only two of them (W1 and W2) had the intact GUS gene (data summarized in Table 2). W2 also had a second insert with a truncated version of $\operatorname{TrAP}$.

The plant W2 was subjected to Northern hybridization analysis with the $\operatorname{Tr} A P$ probe to check whether it was recovered only because $\operatorname{TrAP}$ was not expressed. The RNA from the known TrAP-expressing plant T1.1 (Fig. 2G) hybridized to $\operatorname{Tr} A P$, but no hybridization was seen for the plant W2 (Fig. 3D). Although W1, which had the GUS gene (Table 2), showed GUS activity in histochemical staining (data not shown), W2 had the GUS gene but did not show GUS activity (data not shown). Digestion of DNA of the plant W2 with methylation-sensitive enzymes $A l u \mathrm{I}$ and $M s p \mathrm{I}$ and Southern hybridization analysis with $35 \mathrm{~S}$ promoter probe showed incomplete digestion (data not shown), suggesting methylation of the $35 \mathrm{~S}$ promoter and consequent silencing of TrAP. In summary, upon transformation with $\operatorname{Tr} A P$, only transgenic plants with truncated, missing, or silenced $\operatorname{Tr} A P$ were recovered. These observations provide a strong evidence for the toxicity of TrAP in plants.

\section{The three functional domains of TrAP are associated with toxicity.}

Mutations in the three essential domains of TrAP had been constructed and analyzed earlier (Trinks et al. 2005). In $\triangle$ NLS, three basic amino acids (KKR) within the $\mathrm{N}$-terminal basic domain were replaced by alanine residues destroying the NLS. In $\Delta \mathrm{ZF}$, the first two cysteine residues of the central zinc-finger motif were replaced by alanine residues and, in $\triangle \mathrm{AD}$, amino acids 105 to 135 within the $\mathrm{C}$-terminal acidic activation domain (Hartitz et al. 1999) were deleted. These mutant $\operatorname{Tr} A P$ genes were subcloned in the binary plasmid pCAMBIA1300 to yield pCAM- $\triangle \mathrm{ZF}$ (Fig. 4A), pCAM- $\mathrm{NLS}$ (Fig. 5A), and pCAM- $\triangle \mathrm{AD}$ (Fig. 6A).

In all, 10 transgenic plants (Z1 to Z10) were obtained by transformation with pCAM- $\triangle \mathrm{ZF}, 13$ (N1 to N13) with pCAMNLS, and 12 (A1 to A12) with pCAM- $\triangle A D$. Southern blot analysis showed that all of these had one to several integrated copies of the T-DNA with the $H P H$ gene (Figs. 4B, 5B, and 6B) 
and most of them with the intact TrAP mutant (Figs. 4C, 5C, and 6C) in obvious contrast to the wild-type $\operatorname{Tr} A P$ experiments (Fig. $3 \mathrm{C})$. Exceptions were $\mathrm{Z} 8$ and N2, where the mutated $\operatorname{Tr} A P$ was deleted and N6, A6, and A7, where it was truncated.

Northern analysis was carried out in a selection of these transgenic plants (with one to three copies of the T-DNA) (Fig. $7 \mathrm{~A}$ and B). Except for plant N7 ( $\triangle \mathrm{NLS})$, all of the analyzed plants accumulated the $\operatorname{Tr} A P$ transcript, suggesting that the mutated $\operatorname{Tr} A P$ genes were transcribed well in these transgenic plants. Obviously, the expression of the mutated $\operatorname{Tr} A P$ gene did not cause any toxic effect in the transgenic plants.

\section{DISCUSSION}

We used tobacco as a model system to study the transactivation of the integrated AV1-GUS gene by TrAP in a transgenic plant. pPZP-AV1-transformed tobacco plants unexpectedly showed a moderate amount of TrAP-independent GUS activ-

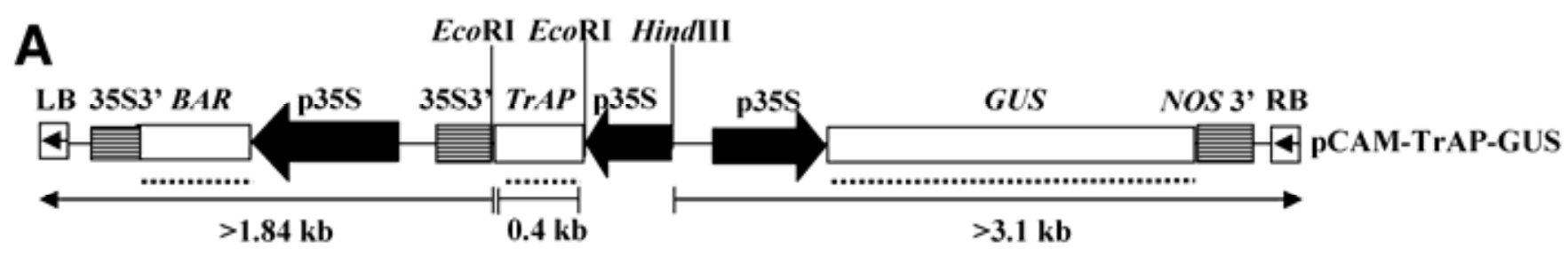

$1 \mathbf{k b}$

EcoRI
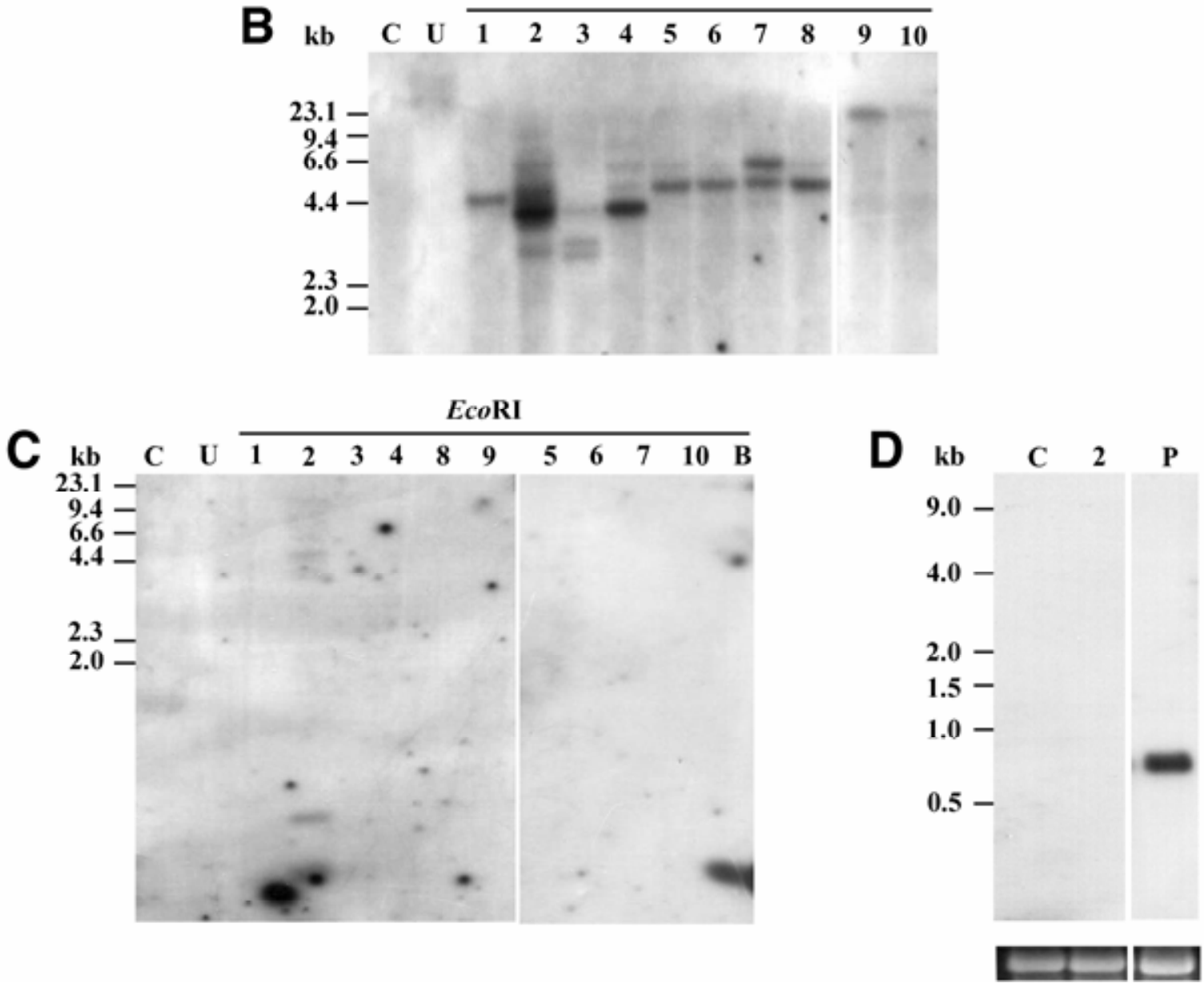

18S rRNA

Fig. 3. Analysis of tobacco plants transformed with wild-type transcriptional activator protein (TrAP) gene. A, pCAM-TrAP- $\beta$-glucuronidase (GUS) harbors wild-type TrAP in pCAMBIA3301. It has the BAR gene as plant transformation marker and GUS gene as reporter gene. B, Southern blot analysis of tobacco plants transformed with pCAM-TrAP-GUS. Total DNA from 10 transformed plants that regenerated and rooted under phosphinothricin selection (W1 to W10) was digested with EcoRI and probed with $B A R$ coding sequence. Undigested DNA from one of the transgenic plants (U) and DNA from nontransgenic control tobacco plant digested with EcoRI (C) were used as controls. $\lambda /$ HindIII was used as marker. Junction fragments of $>1.84 \mathrm{~kb}$ from transgenic plants are expected to hybridize. Results showed that plants W5/W6/W8 and W9/W10 were independent plants that regenerated from the same transformation event. The total number of independently transformed plants is seven. C, DNA from plants W1 to W10 was digested with EcoRI and probed with TrAP coding sequence. The binary plasmid pCAM-TrAP-GUS digested with EcoRI (P) was used as a positive control. $\lambda /$ HindIII was used as marker. An internal T-DNA fragment of $0.4 \mathrm{~kb}$ from transgenic plants and the binary plasmid control (B) is expected to hybridize. D, Northern blot analysis of pCAM-TrAPGUS-transformed plant W2. Total RNA samples from nontransgenic control plant (C) and W2 were electrophoresed in a $1.2 \%$ agarose gel with $1 \%$ formaldehyde and probed with $\operatorname{TrAP}$ coding sequence. RNA from a transgenic tobacco plant which transcribed the TrAP gene was loaded as positive control (P). The 18S rRNA portion of the ethidium-bromide-stained gel is placed at the bottom to show the equal loading of RNA in all the lanes. Sizes of an RNA standard are marked on the left. 
ity. This basal activity, which was due to the enhancer element of the $35 \mathrm{~S}$ promoter of the NPTII gene, was abolished when the $35 \mathrm{~S}$ promoter was replaced by the NOS promoter. This finding agrees with the earlier report of Yoo and associates (2005) and highlighted the importance of avoiding the presence of the $35 \mathrm{~S}$ promoter in the same T-DNA while evaluating the properties of new promoters in transgenic plants. In the present study, we demonstrated that an integrated copy of the $\operatorname{TrAP}$ gene transactivates the AV1 promoter in a transgenic plant. The degree of activation of the AV1 promoter in the transgenic plant T1.1 is relatively low (2.5-fold) but similar to those reported in protoplast systems (Frey et al. 2001; Haley et al. 1992; Sunter and Bisaro 1992; Sunter et al. 1994).

TrAP of ACMV (Hong et al. 1996, 1997), TYLCV-C (van Wezel et al. 2001, 2002), TGMV, and BCTV (Sunter et al.
2001) are reported to function as pathogenicity determinants, perhaps connected to their function as silencing suppressors. TrAP of TGMV causes enhanced susceptibility to the virus in transgenic plants by inactivating SNF1 kinase and redirecting plant metabolism (Hao et al. 2003). The toxicity of MYMV $\operatorname{TrAP}$, interfering with the recovery of TrAP-expressing transgenic tobacco plants, may be a reflection of the pathogenicity factor of TrAP. All transformants obtained with a plasmid containing the $\operatorname{Tr} A P$ gene in addition to a selection marker had integrated T-DNAs in which the TrAP gene was either deleted or truncated or, if present in an intact form, was not expressed. Based on these results, it is clear that $\operatorname{TrAP}$ is inherently toxic to plants.

As reported earlier (Trinks et al. 2005), mutations in ZF, NLS, and $\mathrm{AD}$ of TrAP abolished the activity of TrAP as a transcrip-

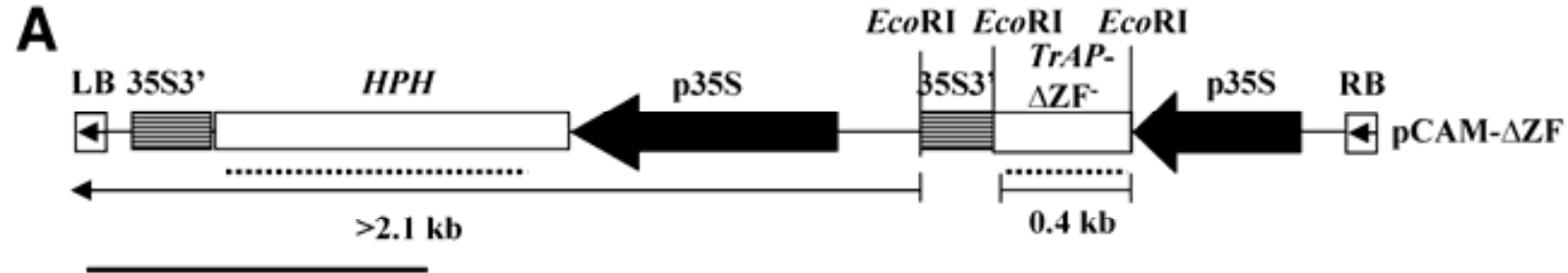

$1 \mathbf{k b}$
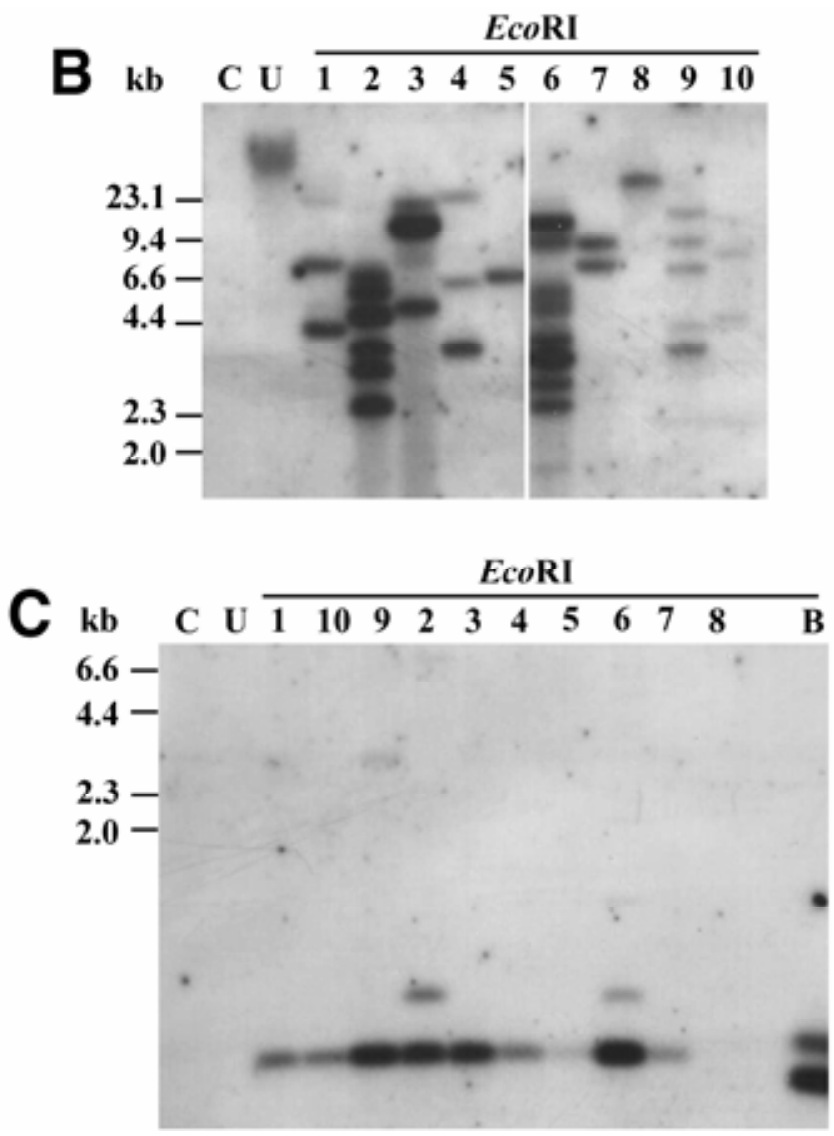

Fig. 4. Analysis of tobacco plants transformed with transcriptional activator protein $(\operatorname{TrAP})$ gene containing mutation in zinc finger (ZF). A, pCAM- $\triangle \mathrm{ZF}$ has $\operatorname{TrAP}$ gene with a mutation in the ZF motif cloned in pCAMBIA1300. Plasmids pCAM- $\triangle \mathrm{ZF}$, pCAM- $\triangle \mathrm{NLS}$, and pCAM- $\triangle \mathrm{AD}$ have hygromycin phosphotransferase gene $(H P H)$ as the plant transformation marker. RB: T-DNA border-right, p35S: Cauliflower mosaic virus (CaMV) 35S promoter, 35S 3': CaMV 35S polyadenylation signal, LB: T-DNA border-left. Probe used is marked in dotted lines. The junction fragment sizes and internal T-DNA (TrAP) size are marked below the arrows. B, Southern blot analysis of tobacco plants transformed with pCAM- $\triangle$ ZF. Total DNA from 10 transformants that regenerated and rooted under hygromycin selection (Z1 to Z10) was digested with EcoRI and probed with $H P H$ coding sequence. Undigested total DNA from one of the transgenic plants (U) and total DNA from the nontransgenic control tobacco plant digested with EcoRI (C) were used as controls. $\lambda /$ HindIII was used as marker. Junction fragments of $>2.1 \mathrm{~kb}$ from transgenic plants are expected to hybridize. C, Southern blot analysis of tobacco plants transformed with pCAM- $\triangle \mathrm{ZF}$ using $\operatorname{TrAP}$ probe. DNA from 10 Southern-positive plants (Z1 to Z10) was digested with EcoRI and probed with $\operatorname{Tr} A P$ coding sequence. The binary plasmid $\triangle \mathrm{pCAM}-\triangle \mathrm{ZF}$ digested with $E c o \mathrm{RI}(\mathrm{B})$ was used as a positive control. An internal T-DNA fragment of $0.4 \mathrm{~kb}$ from transgenic plants and the binary plasmid control (B) is expected to hybridize. 
tional activator and a silencing suppressor. The same mutations also relieved its toxicity, suggesting that the three activities (gene activation, silencing suppression, and toxicity) are linked.

Constitutive expression of HcPro of Turnip mosaic virus, p19 of Tomato bushy stunt virus, and many other silencing suppressors caused developmental defects resembling the pathogenicity of the virus (Chapman et al. 2004; Dunoyer et al. 2004; Kasschau et al. 2003). The pathogenicity is attributed to the interference of silencing suppressors in the miRNA pathway (Kasschau et al. 2003; Silhavy and Burgyan 2004). Similarly, interference with the miRNA-controlled pathways could be the mechanism through which TrAP controls pathogenicity and symptom development. Additionally, transcriptome analysis (Trinks et al. 2005) showed that MYMV TrAP induced expression of a large number of host genes and upregu- lation of one or many of these host genes also could have resulted in toxicity.

Also, TrAP of other begomoviruses (TGMV and ACMV) have been proposed to have toxic effects and difficulties have been reported in generating transgenic plants with them (Hao et al. 2003; Hartitz et al. 1999; Hong et al. 1997; Sunter et al. 2001). Contrary to these results, Chellappan and associates (2005) reported that Arabidopsis plants transformed with TrAP of East African cassava mosaic virus (EACMV) did not have any toxic effect and had a normal phenotype. However, in this case, it was not analyzed whether the TrAP gene remained intact and active.

This study raises the interesting question of how plants cope with the extreme toxicity of TrAP during MYMV infections. It is likely that TrAP may be accumulating at low, subtoxic levels

A

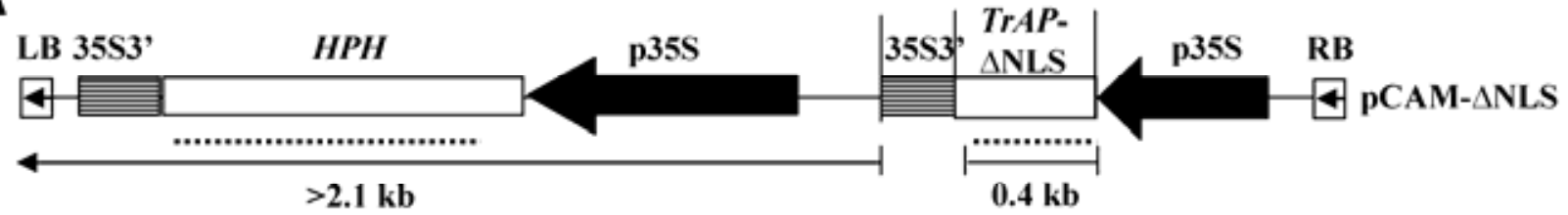

$1 \mathbf{k b}$

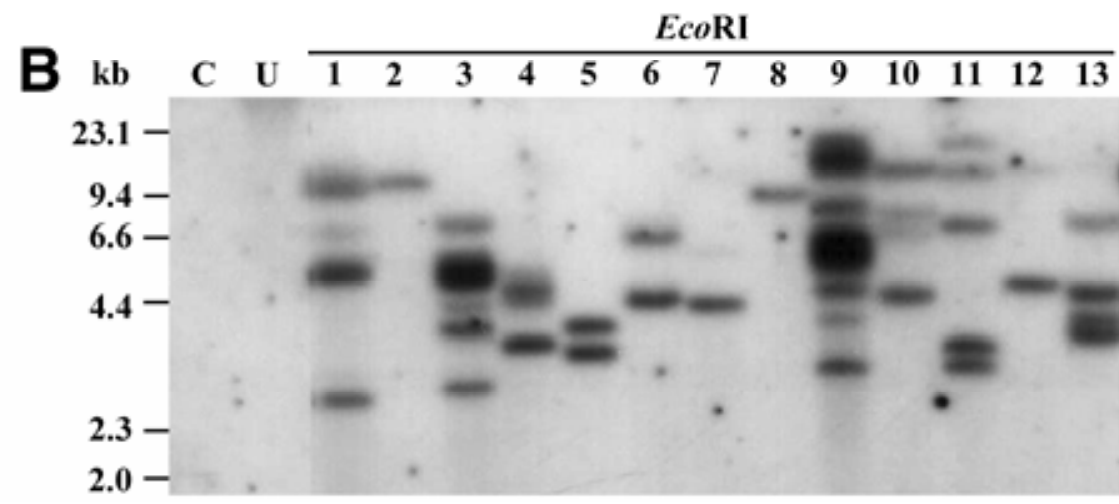

EcoRI

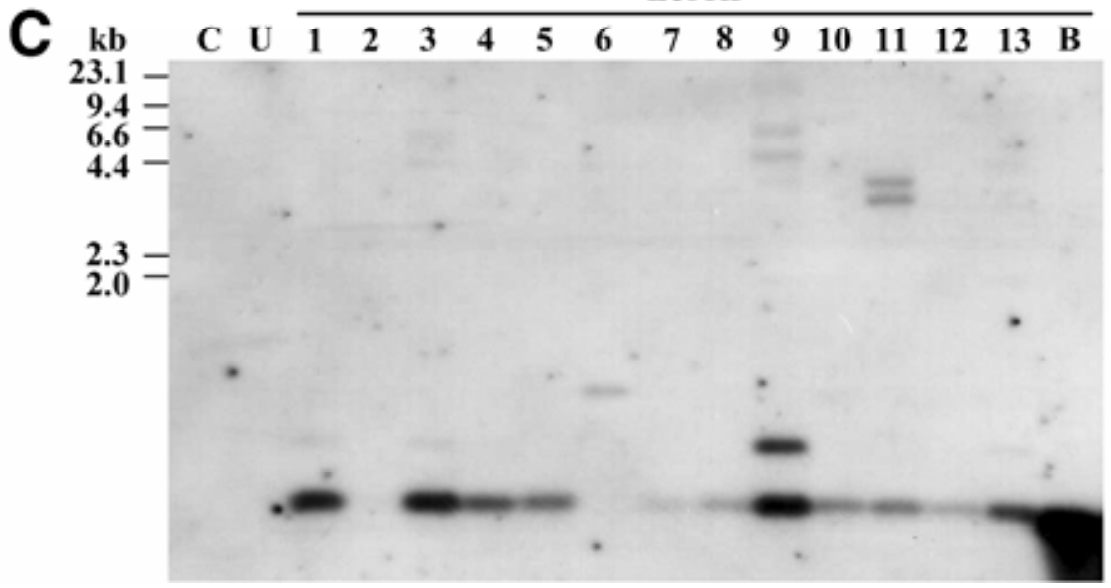

Fig. 5. Analysis of tobacco plants transformed with transcriptional activator protein (TrAP) gene containing mutation in nuclear localization signal. A, pCAM$\triangle$ NLS has TrAP gene with a mutation in the nuclear localization signal in pCAMBIA1300. B, Southern blot analysis of tobacco plants transformed with pCAM- $\triangle$ NLS. Total DNA from 13 transformed plants that regenerated and rooted under hygromycin selection (N1 to N13) was digested with EcoRI and probed with hygromycin phosphotransferase gene coding sequence. Undigested DNA from one of the transgenic plants (U) and DNA from the nontransgenic control tobacco plant digested with $E c o R I(C)$ were used as controls. $\lambda /$ HindIII was used as marker. Junction fragments of $>2.1$ kb from transgenic plants are expected to hybridize. C, Southern blot analysis of tobacco plants transformed with pCAM- $\Delta$ NLS. DNA from 13 hygromycin-resistant Southern-positive plants (N1 to N13) was digested with EcoRI and probed with TrAP coding sequence. An internal T-DNA fragment of 0.4 kb from transgenic plants and the binary plasmid control (B) is expected to hybridize. 


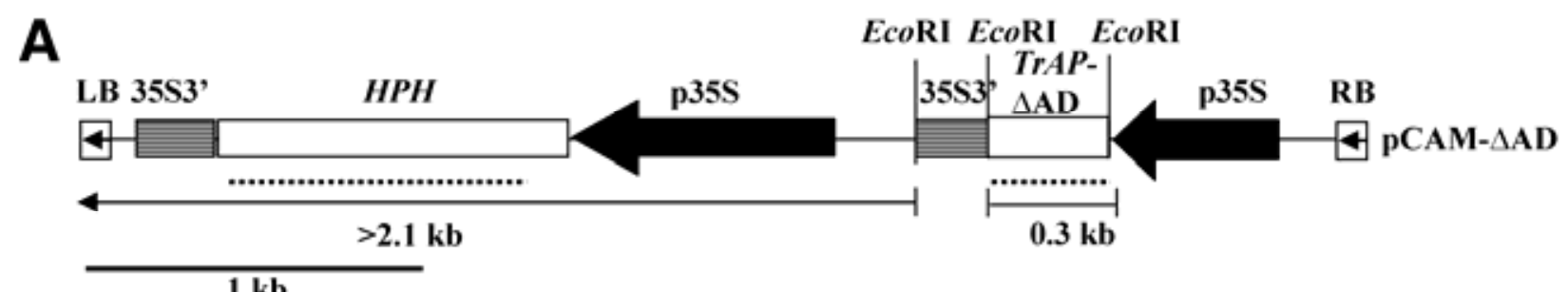

$1 \mathbf{k b}$
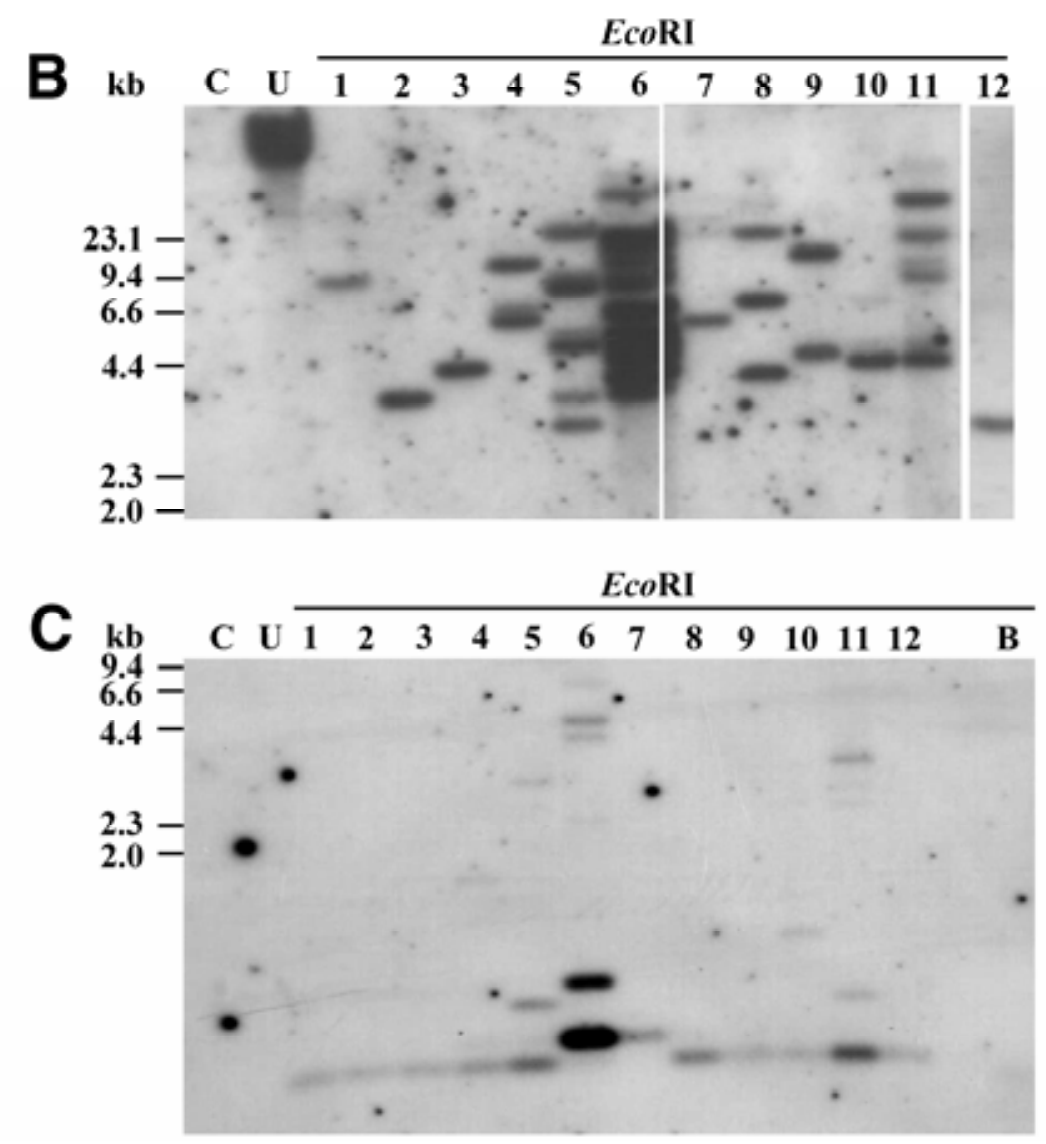

Fig. 6. Analysis of tobacco plants transformed with transcriptional activator protein $(\operatorname{Tr} A P)$ gene with deletion of the activation domain. A, pCAM- $\triangle \mathrm{AD}$ has $\operatorname{TrAP}$ gene with a deletion of the activation domain in pCAMBIA1300. B, Southern blot analysis of tobacco plants transformed with pCAM- $\triangle \mathrm{AD}$. DNA from 12 transformed plants (A1 to A12) that regenerated and rooted under hygromycin selection was digested with EcoRI and probed with hygromycin phosphotransferase gene coding sequence. Junction fragments of $>2.1 \mathrm{~kb}$ from transgenic plants are expected to hybridize. C, Southern blot analysis of tobacco plants transformed with pCAM- $\triangle \mathrm{AD}$. DNA from 12 Southern-positive plants (A1 to A12) was digested with EcoRI and probed with $\operatorname{TrAP}$ coding sequence. An internal T-DNA fragment of $0.3 \mathrm{~kb}$ is expected to hybridize from transgenic plants and the binary plasmid control (B).

in MYMV-infected plants. Alternatively, TrAP in MYMVinfected plants may be sequestered by multiple copies of AV1 and BV1 promoters and, thus, may be diverted from its toxic effect. This could explain how we managed to obtain a TrAPexpressing transgenic plant T1.1 which harbored both AV1 promoter and $\operatorname{Tr} A P$ gene. Additionally, expression of TrAP in rapidly dividing cells during the callus phase of growth in tobacco transformation could be toxic, as against whole plants infected with the virus. The toxic nature of MYMV TrAP can find applications as a negative selection marker in gene targeting (Terada et al. 2004) and for the elimination of transgenic events with "long T-DNA transfers" in which binary vector backbone is transferred to the plants (Hanson et al. 1999).

\section{MATERIALS AND METHODS}

\section{Plasmid constructs.}

The binary plasmid pPZP-AV1 was constructed as follows: A 2.1-kb SalI/EcoRI fragment containing the second exon of the GUS gene and the NOS terminator was subcloned from pIG221 (Ohta et al. 1990) into the corresponding sites of pUC18 (pUC-GUS). A 223-bp fragment containing the first exon of GUS and the bean catalase intron was PCR amplified (cycling conditions: 30 cycles of $95^{\circ} \mathrm{C}$ for $40 \mathrm{~s}, 54^{\circ} \mathrm{C}$ for $40 \mathrm{~s}$, and $72^{\circ} \mathrm{C}$ for $1 \mathrm{~min}$ and a final extension of $72^{\circ} \mathrm{C}$ for $5 \mathrm{~min}$ ) from pIG221 with oligonucleotides $5^{\prime}$-agagcatgcatccctacagg $3^{\prime}$ (with a SphI site, underlined) and 5'-cgagtcgacgtttctgtaac 3' (with a SalI site, underlined). After verifying the sequence, this PCR product was digested with SphI and SalI and cloned upstream of the second exon of GUS gene in pUC-GUS to yield pUC-GUS-int. The 434-bp AV1 promoter fragment between ATG start codon of AC1 (at position 2,599) and the AV1 ATG (at position 307) was PCR amplified (cycling conditions: 30 cycles of $95^{\circ} \mathrm{C}$ for $40 \mathrm{~s}, 54^{\circ} \mathrm{C}$ for $40 \mathrm{~s}$, and $72^{\circ} \mathrm{C}$ for $1 \mathrm{~min}$ and a final extension of $72^{\circ} \mathrm{C}$ for $5 \mathrm{~min}$ ) from MYMV DNA A (GenBank accession number AJ132575) with oligonucleotides $5^{\prime}$ gtctaagcttattttggcg 3' (with a HindIII site, underlined) and 5'ttggcatgcttccgtatac 3' (with a SphI site, underlined). After veri- 


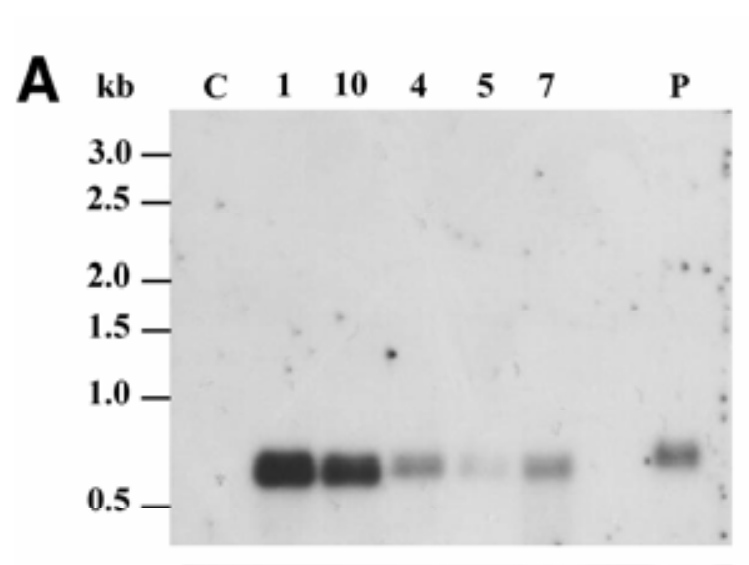

$18 \mathrm{~S}$ rRNA

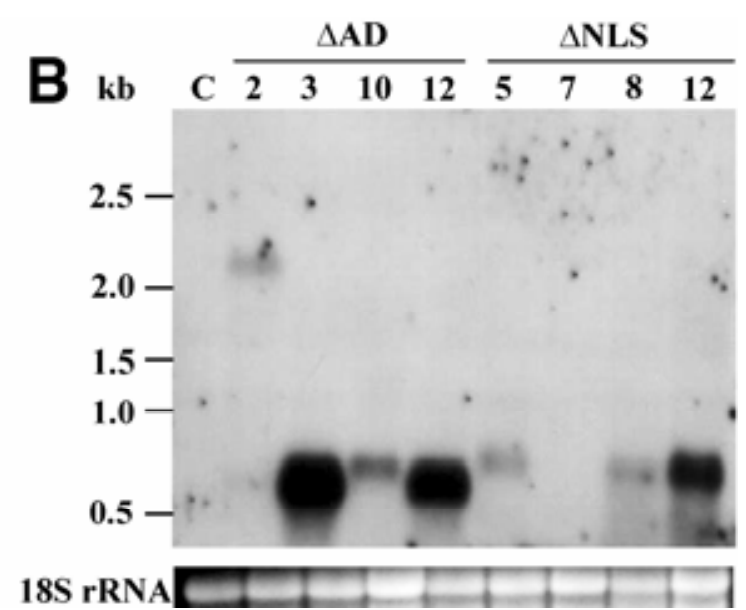

Fig. 7. Northern blot analysis of tobacco plants transformed with transcriptional activator protein $(\operatorname{Tr} A P)$ mutants. A, Total RNA from the nontransgenic plant (C) and five plants $(\mathrm{Z} 1, \mathrm{Z} 10, \mathrm{Z} 4, \mathrm{Z} 5$, and Z7) transformed with pCAM- $\triangle \mathrm{ZF}$ was electrophoresed in a $1.2 \%$ agarose gel with $1 \%$ formaldehyde and probed with $\operatorname{Tr} A P$ coding sequence. A tobacco plant which expresses TrAP gene was loaded as a positive control (P). B, Total RNA from four plants each of pCAM$\triangle$ NLS-transformation and pCAM- $\triangle \mathrm{AD}$-transformation was electrophoresed in a $1.2 \%$ agarose gel with $1 \%$ formaldehyde and probed with $T r A P$ coding sequence. The $18 \mathrm{~S}$ rRNA portion of the ethidium-bromide-stained gel is placed at the bottom to show equal loading of RNA in all the lanes. Sizes of an RNA standard (Ambion, Austin, TX, U.S.A.) are marked on the left.

fication of the sequence, this PCR product was digested with HindIII and SphI and cloned upstream of the first exon of GUS in pUC-GUS-int to create pUC-AV1-GUS. A 2.7-kb AV1-GUS cassette, as an EcoRI/HindIII fragment, was subcloned from pUC-AV1-GUS into the corresponding sites of $\mathrm{pBSIIKS}^{+}$to yield pBS-AV1-GUS. The 2.7-kb AV1-GUS cassette, as an EcoRI/KpnI fragment, was cloned into the corresponding sites of pPZP211 (Hajdukiewicz et al. 1994) to yield pPZP-AV1. pPZP 355 -AV1 was constructed by digestion of pPZP-AV1 with $B g l \mathrm{II}$ and $E c o$ RI, end filled, and self-ligated to remove the 1,049-bp fragment containing the $35 \mathrm{~S}$ promoter. pGA-AV1 was constructed by subcloning the 2.7-kb AV1-GUS cassette as a $S m a \mathrm{I} / K p n \mathrm{I}$ fragment into the $K p n \mathrm{I}$ site and an end-filled XhoI site of pGA472 (An et al. 1985). pCAM-TrAP was constructed as follows: a 477-bp ScaI/DraI fragment from MYMV DNA A (coordinates 1,194 to 1,671 ) containing the TrAP coding sequence was subcloned into the SmaI site of pJIC35S cassette (Hellens et al. 2000) to yield p35S-TrAP. A 1.15-kb EcoRV fragment with 35S-TrAP cassette was subcloned into the SmaI site of pCAMBIA1300 to yield pCAM-TrAP. pCAM-TrAP-GUS was constructed by subcloning the $1.15-\mathrm{kb}$ $35 \mathrm{~S}-\operatorname{Tr} A P$ cassette as an EcoRV fragment from p35S-TrAP into the SmaI site of pCAMBIA3301. TrAP constructs with mutations in NLS, ZF, and AD have been described previously (Trinks et al. 2005). The binary plasmids were mobilized from Escherichia coli into Agrobacterium tumefaciens LBA4404 by triparental mating and mobilizations were confirmed by Southern blot analysis.

\section{Tobacco transformation and transfection of protoplasts.}

Tobacco (N. tabacum L. cv. Wisconsin 38) leaf discs were transformed using Agrobacterium spp. as described earlier (Sunilkumar et al. 1999). Transgenic shoots were rooted in BGS medium (Murashige-Skoog salts, $0.001 \%$ folic acid, myoinositol at $100 \mathrm{mg} / \mathrm{liter}$, thiamine at $0.4 \mathrm{mg} / \mathrm{liter}, 0.057 \mu \mathrm{M}$ indole-3-acetic acid, $0.14 \mu \mathrm{M}$ kinetin, 3\% [wt/vol] sucrose, $0.9 \%$ [wt/vol] agar, $\mathrm{pH}$ 5.7) supplemented with cefotaxime at $250 \mathrm{mg} /$ liter and kanamycin at $50 \mathrm{mg} / \mathrm{liter}$ (for pPZP-AV1 and pGA-AV1), hygromycin at $50 \mathrm{mg} / \mathrm{liter}$ (for pCAM-TrAP, pCAM- $\triangle \mathrm{ZF}$, pCAM- $\triangle \mathrm{NLS}$, and pCAM- $\triangle \mathrm{AD})$ or PPT at 5 mg/liter (for pCAM-TrAP-GUS). Transient expression in $N$. plumbaginifolia leaf protoplasts was performed as described by Trinks and associates (2005). GUS histochemical staining and GUS fluorometric assay were performed as described by Sunilkumar and associates (1999).

\section{Southern and Northern blot analysis.}

Total DNA was extracted as described by Rogers and Bendich (1994). Plant DNA was estimated using a Hoefer DNA fluorometer (DyNA Quant 200) using Hoechst dye 33258. DNA samples $(10 \mu \mathrm{g})$ from control and transgenic tobacco plants were digested with appropriate enzymes, electrophoresed in 0.8 or $1 \%$ agarose gels in $1 \times$ Tris-borate-EDTA, and subjected to Southern blot analysis. Total RNA extraction and Northern hybridization analysis was carried out as described by Pawlowski and associates (1994).

\section{ACKNOWLEDGMENTS}

This work was supported by the Indo-Swiss Collaboration in Biotechnology (DBT, Government of India \& SDC, Switzerland), the Swiss National funds and the Centre for Plant Molecular Biology (DBT, Government of India). We thank M. Muller for preparing excellent protoplasts; S. B. Gelvin, Purdue University, U.S.A. and R. Jefferson, CAMBIA, Australia for Agrobacterium strains and binary plasmids; and K. Dharmalingam, School of Biotechnology, Madurai Kamaraj University for allowing us to use his lab facilities.

\section{LITERATURE CITED}

An, G., Watson, B. D., Stachel, S., Gordon, M. P., and Nester, E. W. 1985. New cloning vehicles for transformation of higher plants. EMBO (Eur. Mol. Biol. Organ.) J. 4:277-284.

Arguello-Astorga, G. R., Guevara-Gonzalez, R. G., Herrera-Estrella, L. R., and Rivera-Bustamante, R. F. 1994. Geminivirus replication origins have a group-specific organization of iterative elements: A model for replication. Virology 203:90-100.

Bisaro, D. M. 2006. Silencing suppression by geminivirus proteins. Virology 344:158-168

Chapman, E. J., Prokhnevsky, A. I., Gopinath, K., Dolja, V. V., and Carrington, J. C. 2004. Viral RNA silencing suppressors inhibit the microRNA pathway at an intermediate step. Genes Dev. 18:11791186.

Chellappan, P., Vanitharani, R., and Fauquet, C. M. 2005. MicroRNAbinding viral protein interferes with Arabidopsis development. Proc. Natl. Acad. Sci. U.S.A. 102:10381-10386.

Dong, X., van Wezel, R., Stanley, J., and Hong, Y. 2003. Functional characterization of the nuclear localization signal for a suppressor of posttranscriptional gene silencing. J. Virol. 77:7026-7033.

Dry, I., Krake, L., Mullineaux, P., and Rezaian, A. 2000. Regulation of to- 
mato leaf curl viral gene expression in host tissues. Mol. Plant-Microbe Interact. 13:529-537.

Dunoyer, P., Lecellier, C. H., Parizotto, E. A., Himber, C., and Voinnet, O. 2004. Probing the microRNA and small interfering RNA pathways with virus-encoded suppressors of RNA silencing. Plant Cell 16:1235-1250.

Fauquet, C. M., and Stanley, J. 2005. Revising the way we conceive and name viruses below the species level: A review of geminivirus taxonomy calls for new standardized isolate descriptors. Arch. Virol. 150:2151-2179.

Frey, P. M., Scharer-Hernandez, N. G., Futterer, J., Potrykus, I., and Puonti-Kaerlas, J. 2001. Simultaneous analysis of the bidirectional African cassava mosaic virus promoter activity using two different luciferase genes. Virus Genes 22:231-242.

Hajdukiewicz, P., Svab, Z., and Maliga, P. 1994. The small, versatile pPZP family of Agrobacterium binary vectors for plant transformation. Plant Mol. Biol. 25:989-994.

Haley, A., Zhan, X., Richardson, K., Head, K., and Morris, B. 1992. Regulation of the activities of African cassava mosaic virus promoters by the $\mathrm{AC} 1, \mathrm{AC} 2$, and AC3 gene products. Virology 188:905-909.

Hanson, B., Engler, D., Moy, Y., Newman, B., Ralston, E., and Gutterson, N. 1999. A simple method to enrich an Agrobacterium-transformed population for plants containing only T-DNA sequences. Plant J. 19:727-734

Hao, L., Wang, H., Sunter, G., and Bisaro, D. M. 2003. Geminivirus AL2 and L2 proteins interact with and inactivate SNF1 kinase. Plant Cell 15:1034-1048.

Hartitz, M. D., Sunter, G., and Bisaro, D. M. 1999. The Tomato golden mosaic virus transactivator (TrAP) is a single-stranded DNA and zincbinding phosphoprotein with an acidic activation domain. Virology 263:1-14.

Hellens, R. P., Edwards, E. A., Leyland, N. R., Bean, S., and Mullineaux. P. M. 2000. pGreen: A versatile and flexible binary Ti vector for Agrobacterium-mediated plant transformation. Plant Mol. Biol. 42:819-832.

Hong, Y., Saunders, K., Hartley, M. R., and Stanley, J. 1996. Resistance to geminivirus infection by virus-induced expression of dianthin in transgenic plants. Virology 220:119-127.

Hong, Y., Saunders, K., and Stanley, J. 1997. Transactivation of dianthin transgene expression by African cassava mosaic virus AC2. Virology 228:383-387.

Karthikeyan, A. S., Vanitharani, R., Balaji, V., Anuradha, S., Thillaichidambaram, P., Shivaprasad, P. V., Parameswari, C., Balamani, V., Saminathan, M., and Veluthambi, K. 2004. Analysis of an isolate of Mungbean yellow mosaic virus (MYMV) with a highly variable DNA B component. Arch. Virol. 149:1643-1652.

Kasschau, K. D., Xie, Z., Allen, E., Llave, C., Chapman, E. J., Krizan, K. A., and Carrington, J. C. 2003. P1/HC-Pro, a viral suppressor of RNA silencing, interferes with Arabidopsis development and miRNA function. Dev. Cell 4:205-217.

Krake, L. R., Rezaian, M. A., and Dry, I. B. 1998. Expression of the tomato leaf curl geminivirus $\mathrm{C} 4$ gene produces virus-like symptoms in transgenic plants. Mol. Plant-Microbe Interact. 11:413-417.

Noris, E., Jupin, I., Accotto, G.P., and Gronenborn, B. 1996. DNA-binding activity of the $\mathrm{C} 2$ protein of tomato yellow leaf curl geminivirus. Virology 217:607-612.

Ohta, S., Mita, S., Hattori, T., and Nakamura, K. 1990. Construction and expression in tobacco of a $\beta$-glucuronidase (GUS) reporter gene containing an intron within the coding sequence. Plant Cell Physiol. 31:805-813.

Pawlowski, K., Kunze, R., DeVries, S., and Bisseling, T. 1994. Isolation of total, poly(A) and polysomal RNA from plant tissues. Pages D5/1D5/13 in: Plant Molecular Biology Manual. S. B. Gelvin and R. A. Schilperoort, eds. Kluwer Academic Publishers, Dordrecht, The Netherlands.

Qazi, J., Ilyas, M., Mansoor, S., and Briddon, R. W. 2007. Legume yellow mosaic viruses: Genetically isolated begomoviruses. Mol. Plant Pathol. 8:343-348.

Rigden, J. E., Krake, L. R., Rezaian, M. A., and Dry, I. B. 1994. ORF C4 of tomato leaf curl geminivirus is a determinant of symptom severity. Virology 204:847-850.

Rogers, S. O., and Bendich, A. J. 1994. Extraction of total cellular DNA from plants, algae and fungi. Pages D1:1-8 in: Plant Molecular Biology Manual. S. B. Gelvin and R. A. Schilperoort, eds. Kluwer Academic Publishers, Dordrecht, The Netherlands.

Ruiz-Medrano, R., Guevara-Gonzalez, R. G., Arguello-Astorga, G. R., Monsalve-Fonnegra, Z., Herrera-Estrella, L. R., and Rivera-Bustamante, R. F. 1999. Identification of a sequence element involved in AC2mediated transactivation of the Pepper huasteco virus coat protein gene. Virology 253:162-169.

Saunders, K., and Stanley, J. 1995. Complementation of African cassava mosaic virus AC2 gene function in a mixed bipartite geminivirus infection. J. Gen. Virol. 76:2287-2292.

Shivaprasad, P. V., Akbergenov, R., Trinks, D., Rajeswaran, R., Veluthambi, K., Hohn, T., and Pooggin, M. M. 2005. Promoters, transcripts, and regulatory proteins of mungbean yellow mosaic geminivirus. J. Virol 79:8149-8163.

Silhavy, D., and Burgyan, J. 2004. Effects and side-effects of viral RNA silencing suppressors on short RNAs. Trends Plant Sci. 9:76-83.

Sunilkumar, G., Vijayachandra, K., and Veluthambi, K. 1999. Preincubation of cut tobacco leaf explants promotes Agrobacterium-mediated transformation by increasing vir gene induction. Plant Sci. 141:51-58.

Sunter, G., and Bisaro, D. M. 1991. Transactivation in a geminivirus: AL2 gene product is needed for coat protein expression. Virology 180:416419.

Sunter, G., and Bisaro, D. M. 1992. Transactivation of geminivirus AR1 and BR1 gene expression by the viral AL2 gene product occurs at the level of transcription. Plant Cell 4:1321-1331.

Sunter, G., and Bisaro, D. M. 1997. Regulation of a geminivirus coat protein promoter by AL2 protein (TrAP): Evidence for activation and derepression mechanisms. Virology 232:269-280.

Sunter, G., and Bisaro, D. M. 2003. Identification of a minimal sequence required for activation of the Tomato golden mosaic virus coat protein promoter in protoplasts. Virology 305:452-462.

Sunter, G., Stenger, D. C., and Bisaro, D. M. 1994. Heterologous complementation by geminivirus AL2 and AL3 genes. Virology 203:203-210.

Sunter, G., Sunter, J. L., and Bisaro, D. M. 2001. Plants expressing Tomato golden mosaic virus AL2 or Beet curly top virus L2 transgenes show enhanced susceptibility to infection by DNA and RNA viruses. Virology 285:59-70.

Terada, R., Asao, H., and Iida, S. 2004. A large-scale Agrobacterium-mediated transformation procedure with a strong positive-negative selection for gene targeting in rice (Oryza sativa L.). Plant Cell Rep. 22:653659.

Trinks, D., Rajeswaran, R., Shivaprasad, P. V., Akbergenov, R., Oakeley, E. J., Veluthambi, K., Hohn, T., and Pooggin, M. M. 2005. Suppression of RNA silencing by a geminivirus nuclear protein, $\mathrm{AC} 2$, correlates with transactivation of host genes. J. Virol. 79:2517-2527.

Vanitharani, R., Chellappan, P., and Fauquet, C. M. 2005. Geminiviruses and RNA silencing. Trends Plant Sci. 10:144-151.

van Wezel, R., Dong, X., Liu, H., Tien, P., Stanley, J., and Hong, Y. 2002. Mutation of three cysteine residues in Tomato yellow leaf curl virusChina C2 protein causes dysfunction in pathogenesis and posttranscriptional gene-silencing suppression. Mol. Plant-Microbe Interact. 15:203208.

van Wezel, R., Liu, H., Tien, P., Stanley, J., and Hong, Y. 2001. Gene C2 of the monopartite geminivirus Tomato yellow leaf curl virus-China encodes a pathogenicity determinant that is localized in the nucleus. Mol. Plant-Microbe Interact. 14:1125-1128.

van Wezel, R., Liu, H., Wu, Z., Stanley, J., and Hong, Y. 2003. Contribution of the zinc finger to zinc and DNA binding by a suppressor of posttranscriptional gene silencing. J. Virol. 77:696-700.

Voinnet, O., Pinto, Y. M., and Baulcombe, D. C. 1999. Suppression of gene silencing: A general strategy used by diverse DNA and RNA viruses of plants. Proc. Natl. Acad. Sci. U.S.A. 96:14147-14152.

Wang, H., Buckley, K. J., Yang, X., Buchmann, R. C., and Bisaro, D. M. 2005. Adenosine kinase inhibition and suppression of RNA silencing by geminivirus AL2 and L2 proteins. J. Virol. 79:7410-7418.

Yoo, S. Y., Bomblies, K., Yoo, S. K., Yang, J. W., Choi, M. S., Lee, J. S. Weigel, D., and Ahn, J. H. 2005. The 35S promoter used in a selectable marker gene of a plant transformation vector affects the expression of the transgene. Planta 221:523-530. 